\title{
Pyridyl-Acyl Hydrazone Rotaxanes and Molecular Shuttles
}

DOI:

10.1021/jacs.7b03307

\section{Document Version}

Accepted author manuscript

Link to publication record in Manchester Research Explorer

\section{Citation for published version (APA):}

Leigh, D., Marcos Algaba, V., Nalbantoglu, T., Vitorica-Yrezabal, I., Tuba Yasar, F., \& Zhu, X. (2017). Pyridyl-Acyl Hydrazone Rotaxanes and Molecular Shuttles. Journal of the American Chemical Society, 7104-7109. https://doi.org/10.1021/jacs.7b03307

\section{Published in:}

Journal of the American Chemical Society

\section{Citing this paper}

Please note that where the full-text provided on Manchester Research Explorer is the Author Accepted Manuscript or Proof version this may differ from the final Published version. If citing, it is advised that you check and use the publisher's definitive version.

\section{General rights}

Copyright and moral rights for the publications made accessible in the Research Explorer are retained by the authors and/or other copyright owners and it is a condition of accessing publications that users recognise and abide by the legal requirements associated with these rights.

\section{Takedown policy}

If you believe that this document breaches copyright please refer to the University of Manchester's Takedown Procedures [http://man.ac.uk/04Y6Bo] or contact uml.scholarlycommunications@manchester.ac.uk providing relevant details, so we can investigate your claim.

\section{OPEN ACCESS}




\title{
Pyridyl-Acyl Hydrazone Rotaxanes and Molecular Shuttles
}

\author{
David A. Leigh*, Vanesa Marcos, Tugrul Nalbantoglu, Iñigo J. Vitorica-Yrezabal, F. Tuba Yasar, \\ Xiaokang Zhu ${ }^{\top}$ \\ School of Chemistry, University of Manchester, Oxford Road, Manchester, M13 9PL, UK \\ ` Present address: College of Pharmaceutical Sciences, Southwest University, Chongqing, 400715, PRC \\ Keywords: Light-driven molecular shuttles, rotaxanes, hydrazones, hydrogen bonding
}

\begin{abstract}
We report on rotaxanes featuring a pyridyl-acyl hydrazone moiety on the axle as a photo-/thermalswitchable macrocycle binding site. The pyridyl-acyl E-hydrazone acts as a hydrogen bonding template that directs the assembly of a benzylic amide macrocycle around the axle to form [2] rotaxanes in up to $85 \%$ yield; the corresponding $Z$ hydrazone thread affords no rotaxane under similar conditions. However, the $E$-rotaxane can be smoothly converted into the Z-rotaxane in $98 \%$ yield under UV irradiation. The X-ray crystal structures of the $E$ - and Z-rotaxanes show different intercomponent hydrogen bonding patterns. In molecular shuttles containing pyridyl-acyl hydrazone and succinic amide ester binding sites, the change of position of the macrocycle on the thread can be achieved through a series of light irradiation and heating cycles with excellent positional integrity $(>95 \%)$ and switching fidelity $(98 \%)$ in each state.
\end{abstract}

\section{INTRODUCTION}

Light and heat are attractive stimuli with which to control the positions of components of molecular machines, both in solution and on surfaces. ${ }^{1}$ Light can be directed to a precise area, the wavelength can be controlled to influence only certain functional groups, and many photochemical reactions generate few byproducts. ${ }^{2}$ Although more challenging to apply to a localized area, heating is similarly often highly efficient and often produces little or no waste. ${ }^{3}$

Rotaxanes in which the macrocycle can be switched between two or more sites, stimuli-responsive molecular shuttles, ${ }^{4-8}$ have been extensively investigated as prototypical molecular machines. ${ }^{9}$ Although a number of light- and thermally-switchable molecular shuttles have been developed, ${ }^{10}$ many suffer from performance issues, such as (i) modest positional integrity in one or both switch states (or systems restricted to small amplitude movements), (ii) one state is short-lived (or only stable under particular conditions), and/or (iii) poor switching fidelity (incomplete formation of one of the states). Amide-based molecular shuttles tend not to suffer from the first problem, highly directional hydrogen bonding can provide precise intercomponent positioning in both switch states even with large distances between the binding sites on the thread." However, light-induced naphthalimide radicals ${ }^{\text {of }}$ are only transiently formed and photoisomerization of fumaramide to maleamide generally gives only a $\sim 50: 50 \quad E: Z$ photostationary state. ${ }^{\text {oh }}$ Here we report on a photo-switchable binding site for a benzylic amide macrocycle that when introduced into a [2] rotaxane overcomes all three of the problems that have detracted from previous lightand/or thermally-switchable molecular shuttle designs.

The new rotaxanes contain an pyridyl-acyl hydrazone unit, ${ }^{12}$ which in the $E$-form of the $\mathrm{C}=\mathrm{N}$ imine-type bond features hydrogen bond-accepting sites in a similar spatial arrangement to other efficient templates for the assembly of benzylic amide macrocycles, ${ }^{13}$ and can undergo $E / Z$ isomerization in response to photochemical or thermal stimuli in high conversion to both states. ${ }^{\text {12a-c }}$ In the $Z$-form the 2-pyridyl ring can form a sixmembered intramolecular hydrogen bond with the amide $\mathrm{N}-\mathrm{H}$ of the hydrazone. We reasoned that when incorporated into a molecular shuttle, the readily switchable $E$ - and $Z$ - forms of the pyridyl-acyl hydrazone should have significantly different binding affinities for the macrocycle, meaning that the position of the ring on the thread should be switchable with high positional integrity.

\section{RESULTS AND DISCUSSION}

2.1 Synthesis and E/Z-Isomerization of Pyridyl-Acyl Hydrazone-Containing [2] Rotaxanes

A stoppered pyridyl-acyl E-hydrazone thread $(E-3)$ was synthesized in six steps from commercially available 
starting materials (Scheme 1 and Supporting Information). Upon UV irradiation (step ii, Scheme 1) E-3 thread was isomerized to the $Z$ form $(Z-3,91 \%$ yield). There are substantial differences in the ${ }^{1} \mathrm{H}$ NMR spectra of the $E$ - and $Z$-hydrazones (Figure 1a and $1 d$ ). One significant change is the downfield shift of the $\mathrm{NH}$ proton of the hydrazone $\left(\Delta \delta \mathrm{H}_{\mathrm{h}}=5.88 \mathrm{ppm}\right)$, which could be rationalized by internal $\mathrm{H}$-bonding to the pyridyl nitrogen. Both $E$ and $Z$-forms of the thread were subjected to rotaxane-forming conditions using an eight-fold excess of isophthaloyl dichloride and $p$-xylylenediamine in $\mathrm{CHCl}_{3}$ in the presence of $\mathrm{Et}_{3} \mathrm{~N}$ (step iv, Scheme 1). Pleasingly, $E-3$ yielded the desired [2] rotaxane $E-4$ in $85 \%$ yield (cf. $62 \%$ glycylglycine ${ }^{13 d}$ and $50 \%$ succinamide ${ }^{13 g}$ threads using similar rotaxane-forming protocols) whereas the $Z$-thread did not afford the corresponding rotaxane, confirming that the pyridyl-acyl Z-hydrazone does not have a suitable arrangement of hydrogen bond acceptors. However, rotaxane Z-4 was smoothly generated from $E-4$ in $98 \%$ yield by UV irradiation (step v, Scheme 1). The $Z$-isomers of both thread and rotaxane (Z-3 and Z-4) are stable in solid form and in solution, with no conversion back to the corresponding $E$-isomers observed in a week at room temperature. However, the $E$-isomers could be rapidly reformed from their Zisomer counterparts by heating at $40^{\circ} \mathrm{C}$ in the presence of a catalytic amount of trifluoroacetic acid (TFA), followed by neutralization with $\mathrm{K}_{2} \mathrm{CO}_{3}$ (98\%, steps iii and vi, Scheme 1). The switching processes were repeated several times without any signs of degradation or loss of fidelity of the switching mechanism.

The ${ }^{1} \mathrm{H}$ NMR spectra of rotaxanes $E-4$ and $Z-4\left(\mathrm{CD}_{2} \mathrm{Cl}_{2}\right.$, $298 \mathrm{~K}$, Figure $1 \mathrm{~b}$ and $1 \mathrm{c}$ ) confirm that $E / Z$ isomerization of the acyl hydrazone moiety alters the nature and strength of the hydrogen bond network between macrocycle and thread. Substantial differences include splitting of most of the resonances corresponding to the macrocycle and thread protons in $Z-4$ (Figure 1c) apparently due to two rotamers of the hydrazone amide being present. Also significant is the two distinct environments observed for the $\mathrm{NH}$ proton of the hydrazone moiety in $Z-4(\delta=13.90$ and $12.68 \mathrm{ppm})$.

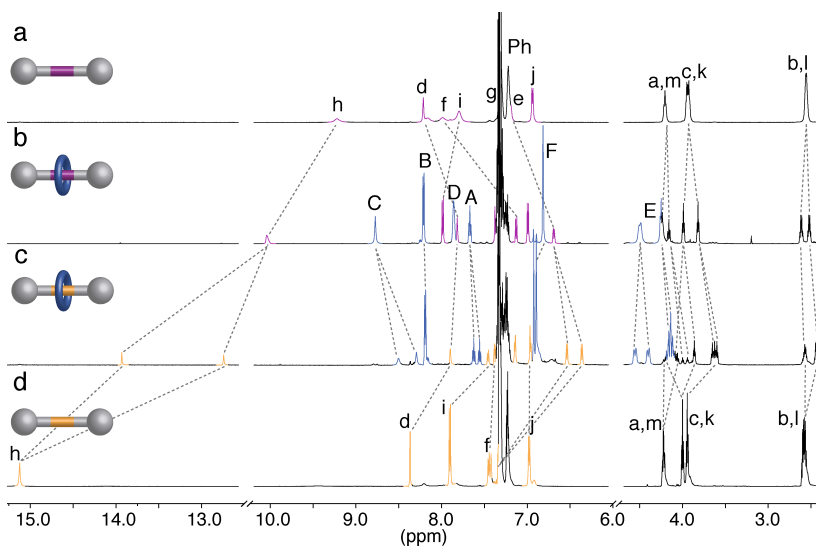

Figure 1. Partial ${ }^{1} \mathrm{H}$ NMR spectra (6oo $\mathrm{MHz}, \mathrm{CD}_{2} \mathrm{Cl}_{2}, 298 \mathrm{~K}$ ) of: a) Thread $E-3$; b) Rotaxane $E-4$; c) Rotaxane Z-4 obtained from irradiation of E-4 with $312 \mathrm{~nm}$ UV light for 1 hour; d) Thread Z-3 obtained from irradiation of E-3 with $312 \mathrm{~nm}$ UV light for $30 \mathrm{~min}$. The lettering and color coding of the signals corresponds to those shown in Scheme 1.

Scheme 1. Synthesis and reversible $E / Z$ isomerization of thread (3) and the corresponding [2]rotaxane (4). 
<smiles>NNC(=O)c1ccc(OCCC(c2ccccc2)c2ccccc2)cc1</smiles>
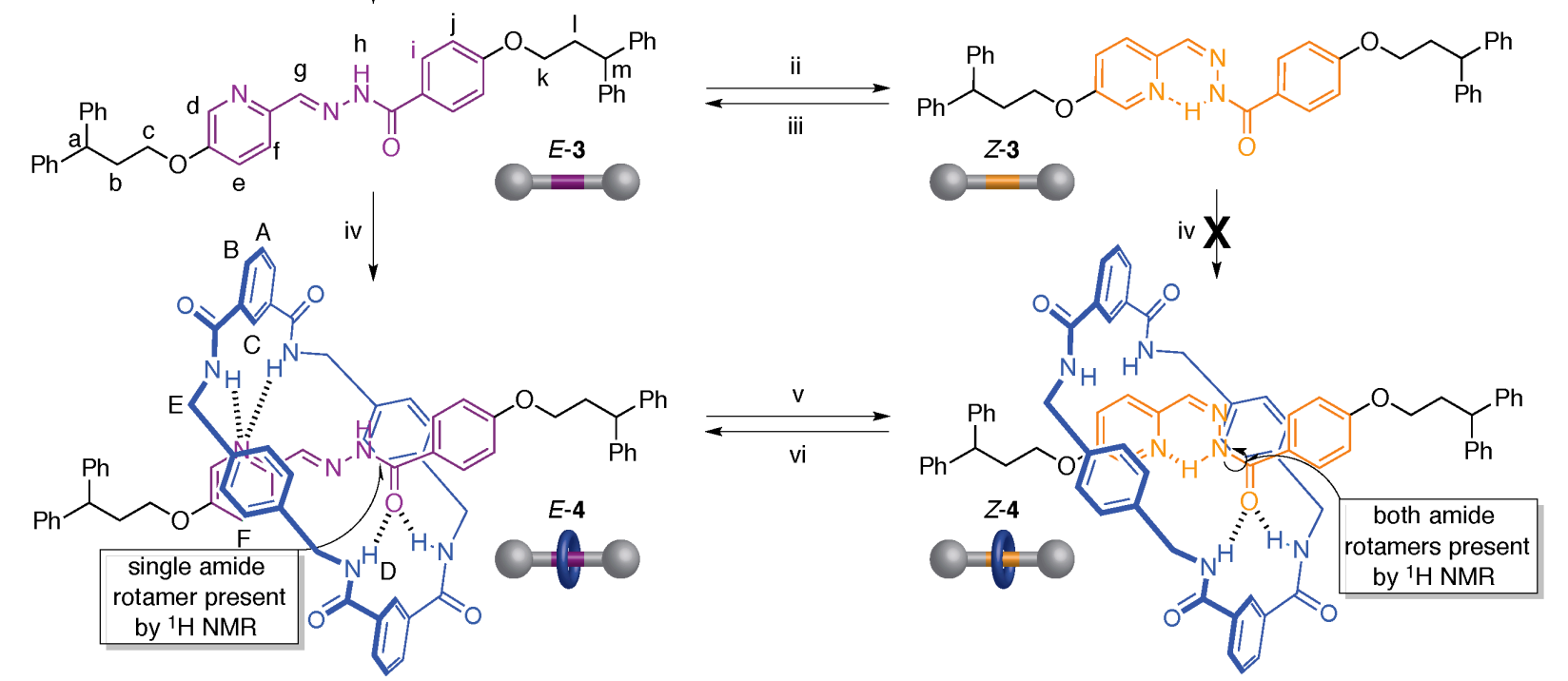

${ }^{a}$ Reaction conditions: (i) AcOH (cat.), EtOH, RT, 18 hours, 8o \%; (ii) $\mathrm{CH}_{2} \mathrm{Cl}_{2}, 312 \mathrm{~nm}$ UV light, RT, 30 min, 91 \%; (iii) TFA (20 mol \%), $\mathrm{CH}_{2} \mathrm{Cl}_{2}, 40{ }^{\circ} \mathrm{C}$, 1 hour, $98 \%$; (iv) p-xylylenediamine (8-fold excess), isophthaloyl dichloride (8-fold excess), Et $3 \mathrm{~N}$ (16-fold excess), $\mathrm{CHCl}_{3}$, RT, 18 hours, $85 \%$; (v) $\mathrm{CH}_{2} \mathrm{Cl}_{2}, 312 \mathrm{~nm}$ UV light, RT, 1 hour, $98 \%$; (vi) TFA (20 mol \%), $\mathrm{CH}_{2} \mathrm{Cl}_{2}, 40{ }^{\circ} \mathrm{C}, 2$ hours, $98 \%$.

Single crystals of each isomer of the rotaxane $(E-4$ and $Z$-4) were obtained by slow evaporation of solutions of each rotaxane in $\mathrm{CH}_{2} \mathrm{Cl}_{2}: \mathrm{CH}_{3} \mathrm{CN}$ (1:1), and the solid-state structures determined by $\mathrm{X}$-ray crystallography (Figures 2 and 3 ). The intercomponent interactions are very different in the two isomers. In the solid state structure of rotaxane $E_{-4}$ (Figure 2) the macrocycle adopts a twistboat-like conformation with one amide hydrogen bonding to the pyridyl ring nitrogen (2.08 $)$ and the other isophthalamide unit adopting bifurcated hydrogen bonds to the carbonyl of the thread $(2.18,2.24 \AA)$. The fourth amide group of the macrocycle engages in hydrogen bonding with a water molecule (2.06 $\AA$ ) which also acts as a hydrogen bond acceptor for the amide $\mathrm{NH}$ $(1.94 \AA)$ of the axle hydrazone. In contrast, in the crystal structure of $\mathrm{Z}-4$ (Figure 3 ) the macrocycle adopts a chair-like conformation with one isophthalamide group forming bifurcated hydrogen bonds $(2.19,2.24 \AA$ ) with the thread carbonyl while one of the other NH groups interacts with the nitrogen atom of the hydrazone through a long $\mathrm{NH} \cdots \mathrm{N}_{\mathrm{sp} 2}$ hydrogen bond (2.35 ̊̊). A sixmembered intramolecular hydrogen bond is formed between the hydrazone proton and the pyridyl nitrogen of the axle (1.91 $\AA$ ), which is presumably the cause of the relatively high thermal stability of the $Z$-isomer compared to typical acyl hydrazones.

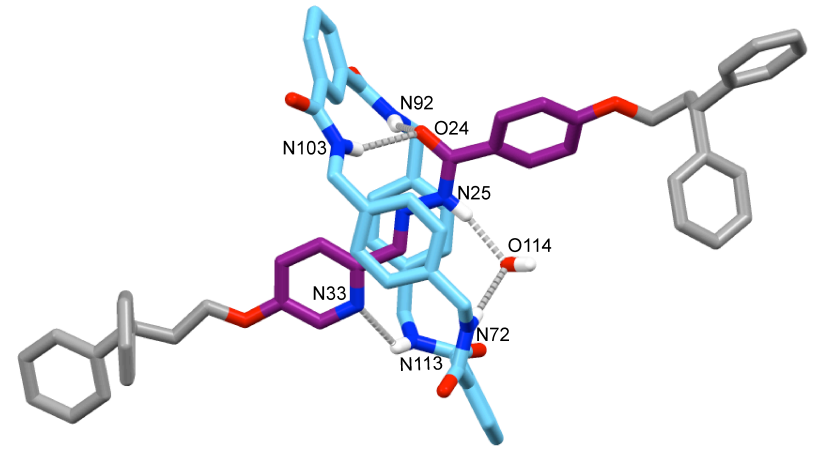

Figure 2. X-ray crystal structure of pyridyl-acyl hydrazone [2] rotaxane E-4. Hydrogen bond lengths $[\AA]$ : $\mathrm{N}_{33}-\mathrm{H}_{113} \mathrm{~N}$, 2.08; O114- $\mathrm{H}_{72} \mathrm{~N}$, 2.06; O114-H25 N, 1.94; O24-H92 N, 2.24; $\mathrm{O}_{24}-\mathrm{H}_{10} \mathrm{~N}, 2.18$. Hydrogen bond angles $\left({ }^{\circ}\right)$ : N113-H-N33, 124.7; N72-H-O114, 155.7; N25-H-O114, 164.7; N92-H-O24, 162.4; N103-H-O24, 143.4. The $\mathrm{O}-\mathrm{H}(0.993 \AA)$ and $\mathrm{N}-\mathrm{H}$ $(1.015 \AA)$ bond distances were normalised to match with neutron diffraction data

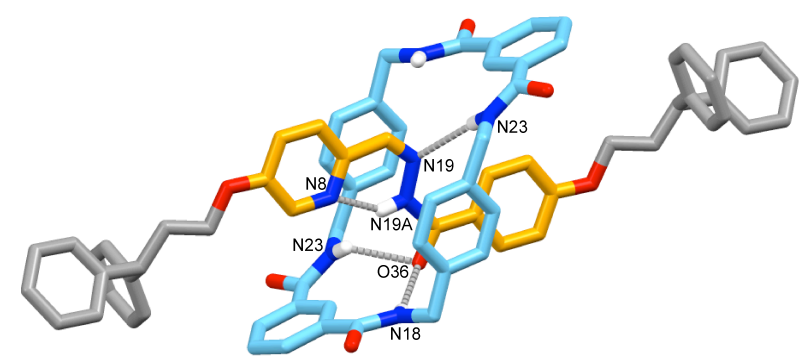

Figure 3. X-ray crystal structure of pyridyl-acyl hydrazone [2] rotaxane Z-4. Hydrogen bond lengths [§]: N8-HigAN, 
1.91; $\mathrm{N}_{19}-\mathrm{H}_{23} \mathrm{~N}, 2.35 ; \mathrm{O}_{3} 6-\mathrm{H}_{23} \mathrm{~N}, 2.19 ; \mathrm{O}_{3} 6-\mathrm{H}_{1} 8 \mathrm{~N}, 2.24$. Hydrogen bond angles $\left({ }^{\circ}\right)$ : N19A-H-N8, 142.3; N23-H-N19, 153.3; N23-H-O36, 155.9; N18-H-O36, 148.9. The $\mathrm{O}-\mathrm{H}$ $(0.993 \AA)$ and $\mathrm{N}-\mathrm{H}(1.015 \AA)$ bond distances were normalised to match with neutron diffraction data.

\subsection{Synthesis and Photo- and Thermal-Switching of a Pyridyl-Acyl Hydrazone Molecular Shuttle.}

The difference in the hydrogen bonding networks of the two rotaxane isomers, $E-4$ and $Z-4$, suggested that it should be possible to modulate the strength of intercomponent binding by photochemical and thermal isomerization in an appropriate rotaxane-based molecular shuttle (Scheme 2). We prepared a molecular shuttle thread $(E-5)$ that features two potential binding sites for the benzylic amide macrocycle, a pyridyl-acyl hydrazone unit and a succinic amide-ester group (Scheme 2). We reasoned that the macrocycle should preferentially bind to the pyridyl-acyl $E$-hydrazone moiety over the succinic amide-ester due to the poor hydrogen bonding ability of the ester group. Photochemical isomerization to the corresponding Z-form would then switch off hydrogen bonding to the pyridyl group and causing the macrocycle to preferentially relocate to the succinic amide-ester binding site.

The pyridyl-acyl $E$-hydrazone-succinamide-ester thread $(E-5)$ was prepared in eight steps from commercially available starting materials (77:23 E/Z ratio, see Supporting Information). Thread $E-5$ could be smoothly isomerized to the Z-5 thread by UV irradiation (91\%, step ii, Scheme 2 and Figures $4 \mathrm{a}$ and $4 \mathrm{~d}$ ) and restored back to the $E$-state through thermal isomerization in the presence of a catalytic amount of trifluoroacetic acid ( $77 \%$, step iii, Scheme 2). Formation of the interlocked architecture using the multi-component clipping reaction furnished [2] rotaxane $E-6$ in $70 \%$ yield (step i, Scheme 2).

Since the xylylene rings of the macrocycle shield the encapsulated regions of the thread, the position of the macrocycle could be determined in each rotaxane state in $\mathrm{CD}_{2} \mathrm{Cl}_{2}$ by comparing the chemical shift of the protons of the rotaxane with the equivalent resonances of the thread. The spectra of each isomer of thread and rotaxane, $E / Z-5$ and $E / Z-6$, are shown in Figure 4 . With the pyridyl-acyl $E$-hydrazone rotaxane (E-6, Figure $4 \mathrm{~b})$, the signal corresponding to the $\mathrm{NH}$ group of the hydrazone $(\Delta \delta=-1.84 \mathrm{ppm})$ and $\mathrm{H}_{\mathrm{a}}$ and $\mathrm{H}_{\mathrm{c}}(\Delta \delta=-0.63$ and -0.83 $\mathrm{ppm})$ are significantly shifted upfield, respectively (comparison of Figure 4a with $4 \mathrm{~b}$ ), whereas resonances of the succinic amide-ester moiety are similar in thread and rotaxane, consistent with the macrocycle being located over the hydrazone binding site. In contrast, the resonances of rotaxane Z-6 (Figure 4c) exhibit a shielding of the protons $\left(\mathrm{H}_{1}\right.$ and $\left.\mathrm{H}_{\mathrm{m}}\right)$ of the succinic amideester unit $(\Delta \delta=-1.19$ and $-1.02 \mathrm{ppm})$, whereas the signals from the acyl hydrazone station remains similar in rotaxane and thread, indicating that the macrocycle is preferentially located around the succinic amide-ester (comparison of Figure 4c with $4 \mathrm{~d}$ ).

Rotaxane $E-\mathbf{6}$ could be smoothly converted to Z-6 with $312 \mathrm{~nm}$ UV light ( $91 \%$ yield) and then restored to the $E$ 6 form upon treatment with $20 \mathrm{~mol} \%$ TFA in $\mathrm{CD}_{2} \mathrm{Cl}_{2}$ at $40{ }^{\circ} \mathrm{C}$ (98\% yield). ${ }^{14}$ From the ${ }^{1} \mathrm{H}$ NMR chemical shift differences we estimate that the macrocycle spends $>95$ $\%$ of the time on the acylpyridyl hydrazone site in E-6 and $>95 \%$ of the time on the succinic amide-ester site in Z-6 (see Supporting Information, Section 3.2). This represents one of the highest switching fidelities between chemical states, and one of the highest degrees of positional discrimination, within both states for a lightand/or thermally-switchable molecular shuttle.

Scheme 2. Synthesis and Switching of Thread 5 and Molecular Shuttle 6. 

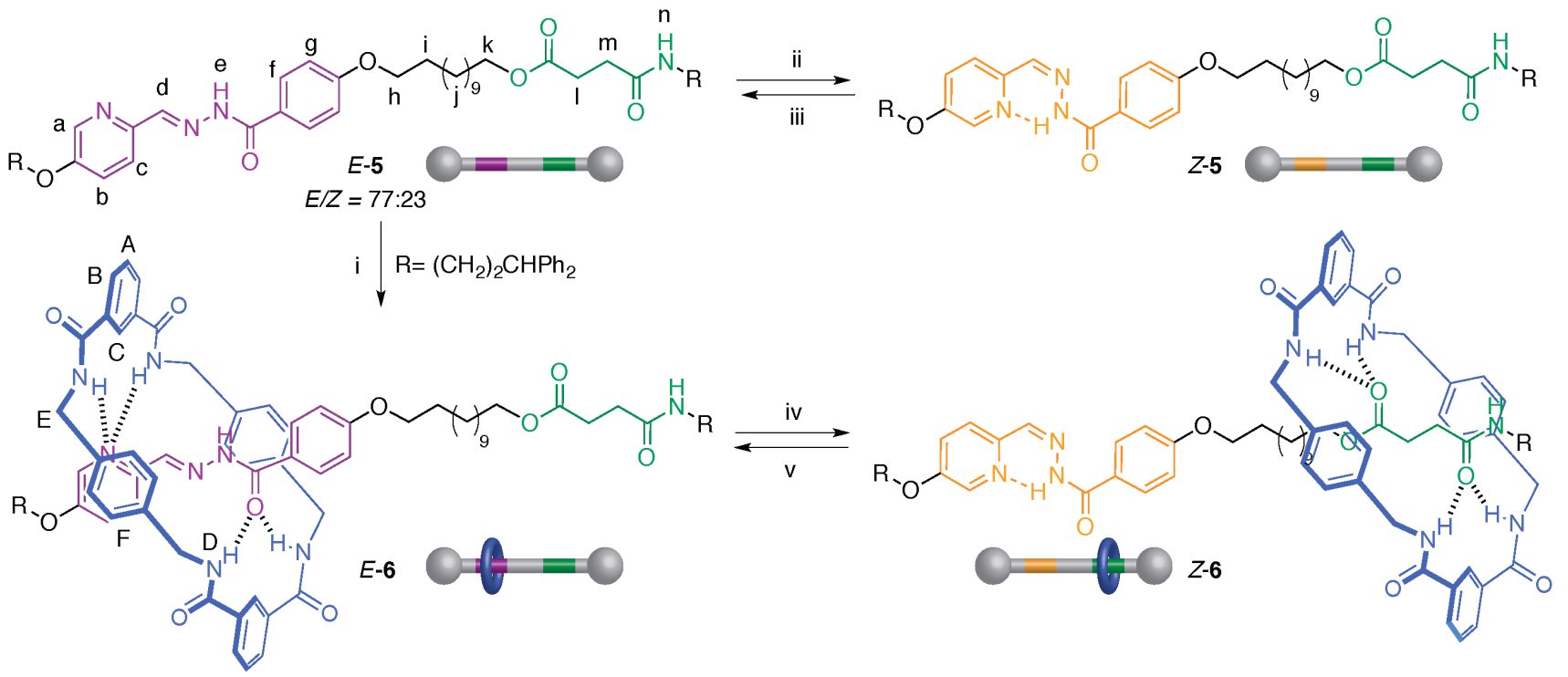

${ }^{a}$ Reaction conditions: (i) p-xylylenediamine (8-fold excess), isophthaloyl dichloride (8-fold excess), $\mathrm{Et}_{3} \mathrm{~N}$ (16-fold excess), $\mathrm{CHCl}_{3}$, RT, 18 hours, $70 \%$; (ii) $\mathrm{CD}_{2} \mathrm{Cl}_{2}, 312 \mathrm{~nm}$ UV light, RT, 1 hour, $91 \%$; (iii) TFA (20 mol \%), $\mathrm{CD}_{2} \mathrm{Cl}_{2}, 40{ }^{\circ} \mathrm{C}, 2$ hours, $77 \%$; (iv) $\mathrm{CD}_{2} \mathrm{Cl}_{2}$, $312 \mathrm{~nm}$ UV light, RT, 2 hours, $91 \%$; (v) TFA (20 mol \%), $\mathrm{CD}_{2} \mathrm{Cl}_{2}, 40{ }^{\circ} \mathrm{C}, 2$ hours, $98 \%$.

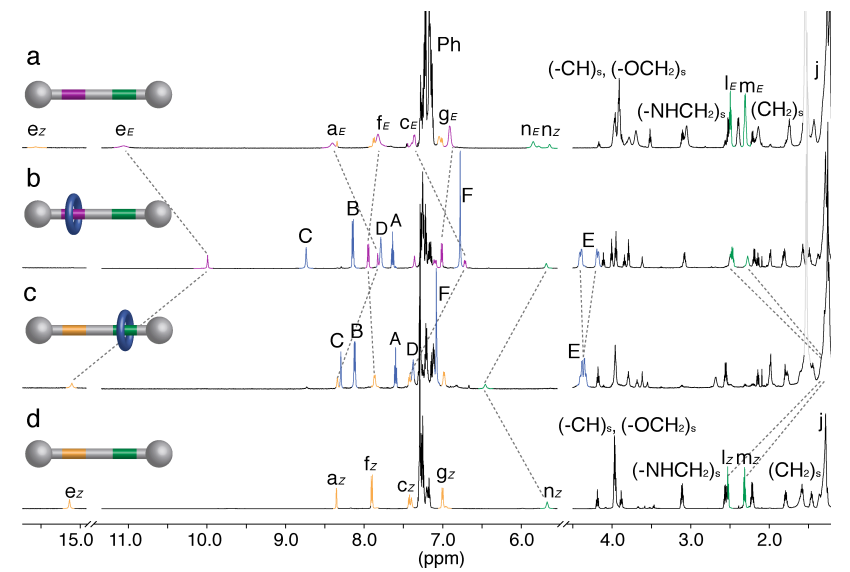

Figure 4. Partial ${ }^{1} \mathrm{H}$ NMR spectra (6oo $\left.\mathrm{MHz}, \mathrm{CD}_{2} \mathrm{Cl}_{2}, 298 \mathrm{~K}\right)$ of: a) Thread $E-5(E / Z=77: 23)$; b) Rotaxane $E-6$; c) Rotaxane Z-6 obtained from irradiation of E-6 with $312 \mathrm{~nm}$ UV light for 2 hours; d) Thread Z-5 obtained from irradiation of E-5 with $312 \mathrm{~nm}$ UV light for 1 hour. The lettering and color coding of the signals corresponds to those shown in Scheme 2. The signals correspond to the protons of the stoppers and aliphatic chain are labeling as $\mathrm{s}$ and $\mathrm{j}$, respectively.

\section{CONCLUSIONS}

Pyridyl-acyl E-hydrazones act as an effective template for the assembly of benzylic amide macrocycle rotaxanes via the classic five-component clipping method. The solid state structures of the $E$ - and $Z$-rotaxanes reveal patterns of intercomponent hydrogen bonding consistent with ${ }^{1} \mathrm{H}$ NMR studies in solution. The $E$ - and $Z$ - forms of the rotaxane can be efficiently interconverted with a high degree of fidelity by photochemical and acid-catalyzed thermal cis-trans isomerizations. Incorporation of the pyridyl-acyl hydrazone group into a bistable stimuli-responsive molecular shuttle affords excellent positional discrimination (>95 \%) and high stability $(98 \%)$ in both states. These features, together with the fact that the rotaxanes are neutral, stable and easy to prepare, suggest that pyridyl-acyl hydrazones should be a useful addition to the motifs available for the construction of switchable molecular shuttles and more complex molecular machines.

\section{ASSOCIATED CONTENT}

Supporting Information. Detailed experimental procedures and spectroscopic data for all the compounds, and full crystallographic data for rotaxanes $E-4$ and $Z-4$ including cif files. This material is available free of charge via the internet at http://pubs.acs.org.

\section{AUTHOR INFORMATION}

\section{Corresponding Author}

*David.Leigh@manchester.ac.uk

Notes

The authors declare no competing financial interest.

\section{ACKNOWLEDGMENTS}

We thank the EPSRC National Mass Spectrometry Centre (Swansea, UK) for high resolution mass spectrometry. This research was funded by the EPSRC and the ERC. DAL is a Royal Society Research Professor.

\section{REFERENCES}

(1) (a) Koumura, N.; Zijlstra, R. W. J.; van Delden, R. A.; Harada, N.; Feringa, B. L. Nature 1999, 401, 152. (b) Leigh, D. A.; 
Wong, J. K. Y.; Dehez, F.; Zerbetto, F. Nature 2003, 424, 174. (c) Hernández, J. V.; Kay, E. R.; Leigh, D. A. Science 2004, 306, 1532. (d) Berná, J.; Leigh, D. A.; Lubomska, M.; Mendoza, S. M.; Peréz, E. M.; Rudolf, P.; Teobaldi, G.; Zerbetto, F. Nat. Mater. 2005, 4, 704. (e) Eelkema, R.; Pollard, M. M.; Vicario, J.; Katsonis, N.; Ramon, B. S.; Bastiaansen, C. W. M.; Broer, D. J.; Feringa, B. L. Nature 2oo6, 440, 163. (f) Balzani, V.; ClementeLeón, M.; Credi, A.; Ferrer, B.; Venturi, M.; Flood, A. H.; Stoddart, J. F. Proc. Natl. Acad. Sci. U.S.A. 2006, 103, 1178. (g) Credi, A.; Venturi, M. Cent. Eur. J. Chem. 2oo8, 6, 325. (h) Balzani, V.; Credi, A.; Venturi, M. Chem. Soc. Rev. 2oo9,38, 1542. (i) Zheng, Y. B.; Hao, Q.; Yang, Y.-W.; Kiraly, B. Chiang, I.-K.; Huang, T. J. J. Nanophoton. 2010, 4, 42501. (j) Silvi, S.; Venturi, M.; Credi, A. Chem. Commun. 2011, 47, 2483. (k) Yang, W.; Li, Y.; Liu, H.; Chi, L.; Li, Y. Small 2012, 8, 504. (l) Aggarwalı, S.; Sharma, A. Int. J. Appl. Eng. Res. 2014, 10, 1199. (m) Ceroni, P.; Credi, A.; Venturi, M. Chem. Soc. Rev. 2014, 43, 4068.

(2) (a) Ciamician, G. Science 1912, 36, 385. (b) Prier, C. K.; Rankic D. A.; MacMillan, D. W. C. Chem. Rev. 2o13, 113, 5322. (c) Narayanam J. M. R.; Stephenson, C. R. J. Chem. Soc. Rev. 2011, 40, 102. (d) Du, J.; Skubi, K. L.; Schultz D. M.; Yoon, T. P. Science, 2014, 344, 392. (e) Schultz, D. M.; Yoon, T. P. Science 2014, 343, 1239176. (f) Blanco, V.; Leigh D. A.; Marcos, V. Chem. Soc. Rev. 2015, 44, 5341. (g) Vlatković, M.; Collins, B. S. L.; Feringa B. L. Chem.-Eur. J. 2016, 22, 17080. (h) Corrigan, N.; Shanmugam, S.; Xu, J.; Boyer, C. Chem. Soc. Rev. 2016, 45, 6165. (i) Skubi, K. L.; Blum, T. R.; Yoon, T. P. Chem. Rev. 2016, 116, 10035

(3) (a) Urry, D. W. Angew. Chem., Int. Ed. 1993, 32, 819. (b) Lee, J. W.; Kim, K.; Kim, K. Chem. Commun. 2oo1, 1042. (c) Asakawa, M.; Brancato, G.; Fanti, M.; Leigh, D. A.; Shimizu, T.; Slawin, A. M. Z.; Wong, J. K. Y.; Zerbetto, F.; Zhang, S. J. Am. Chem. Soc. 2002, 124, 2939. (d) Bottari, G.; Dehez, F.; Leigh, D. A.; Nash, P. J.; Peréz, E. M.; Wong, J. K. Y.; Zerbetto, F. Angew. Chem., Int. Ed. 2003, 42, 5886. (e) Jeppesen, J. O.; Nielsen, K. A.; Perkins, J.; Vignon, S. A.; Di Fabio, A.; Ballardini, R.; Gandolfi, M. T.; Venturi, M.; Balzani, V.; Becher, J.; Stoddart, J. F. Chem.-Eur. J. 2003, 9, 2982. (f) Tu, Y.; Peng, F.; Sui, X.; Men, Y.; White, P. B.; van Hest, J. C. M.; Wilson, D. A. Nature Chem. 2017, 9, 480. (g) Farahani, N.; Zhu, K.; O'Keefe, C. A.; Schurko, R. W.; Loeb, S. J. ChemPlusChem 2016, 81, 836.

(4) For examples of $\mathrm{pH}$-driven molecular shuttles, see: (a) Ashton, P. R.; Ballardini, R.; Balzani, V.; Baxter, I.; Credi, A.; Fyfe, M. C. T.; Gandolfi, M. T.; Gomez-Lopez, M.; MartinezDiaz, M. V.; Piersanti, A.; Spencer, N.; Stoddart, J. F.; Venturi, M.; White A. J. P.; Williams, D. J. J. Am. Chem. Soc. 1998, 120, 11932. (b) Leigh, D. A.; Thomson, A. R. Org. Lett. 2006, 8, 5377. (c) Vella, S. J.; Tiburcio, J.; Loeb, S. J. Chem. Commun. 2007, 4752. (d) Crowley, J. D.; Leigh, D. A.; Lusby, P. J.; McBurney, R. T.; Perret-Aebi, L. E.; Petzold, C.; Slawin, A. M. Z.; Symes, M. D. J. Am. Chem. Soc. 2007, 129, 15085. (e) Coutrot, F.; Busseron, E. Chem.-Eur. J. 2009, 15, 5186. (f) Leigh, D. A.; Thomson, A. R. Tetrahedron 2008, 64, 8411. (g) Jiang, Q.; Zhang, H.-Y.; Han, M.; Ding, Z.-J.; Liu, Y. Org. Lett. 2010, 12, 1728. (h) Jiang, Y.; Guo J.-B.; Chen, C.-F. Org. Lett. 2010, 12, 4248. (i) Zheng, H.; Zhou, W.; Lv, J.; Yin, X.; Li, Y.; Liu, H.; Li, Y. Chem. -Eur. J. 2009, 15, 13253. (j) Gan, Q.; Ferrand, Y.; Bao, C.; Kauffmann, B.; Grélard, A.; Jiang, H.; Huc, I. Science, 2011, 331, 1172. (k) Buyukcakir, O.; Yasar, F. T.; Bozdemir, O. A.; Icli, B.; Akkaya E. U. Org. Lett. 2013, 15, 1012. (1) Riss-Yaw, B.; Waelès, P.; Coutrot, F. Chem. Phys. Chem 2o16, 17, 1; (m) Gao, M.; Han, S.; Hu, Y.; Dynes, J. J.; Liu, X.; Wang, D. RSC Adv. 2016, 6, 27922.

(5) For examples of redox-active molecular shuttles, see: (a) Bissell, R. A.; Córdova, E.; Kaifer, A. E.; Stoddart, J. F. Nature
1994, 369, 133. (b) Anelli, P. -L.; Asakawa, M.; Ashton, P. R.; Bissell, R. A.; Clavier, G.; Gróski, R.; Kaifer, A. E.; Langford, S. J.; Mattersteig, G.; Menzer, S.; Philp, D.; Slawin, A. M. Z.; Spencer, N.; Stoddart, J. F.; Tolley, M. S.; Williams, D. J. Chem. Eur. J. 1997, 3, 1113. (c) Collin, J. -P.; Gavinã, P.; Sauvage, J.-P. New J. Chem. 1997, 21, 525. (d) Armaroli, N.; Balzani, V.; Collin, J.-P.; Gavinã, P.; Sauvage, J.-P.; Ventura, B. J. Am. Chem. Soc. 1999, 121, 4397. (e) Ballardini, R.; Balzani, V.; Dehaen, W.; Dell'Erba, A. E.; Raymo, F. M.; Stoddart, J. F.; Venturi, M. Eur. J. Org. Chem. 20oo, 591. (f) Deng, W.-Q.; Flood, A. H.; Stoddart, J. F.; Goddard, W. A. J. Am. Chem. Soc. 2005, 127, 15994. (g) Stoddart, J. F.; Dey, S. K.; Coskun, A.; Fahrenbach, A. C.; Barin, G.; Basuray, A. N.; Trabolsi, A.; Botros, Y. Y. Chem. Sci. 2011, 2, 1046. (h) Joosten, A.; Trolez, Y.; Collin, J.-P.; Heitz, V.; Sauvage, J.-P. J. Am. Chem. Soc. 2012, 134, 1802. (i) Barnes, J. C.; Fahrenbach, A. C.; Dyar, S. M.; Frasconi, M.; Giesener, M. A.; Zhu, Z.; Liu, Z.; Hartlieb, K. J.; Carmieli, R.; Wasielewski, M. R.; Stoddart, J. F. Proc. Natl. Acad. Sci. U. S. A. 2012, 109, 11546. (j) Coronado, E.; Gaviña, P.; Ponce, J.; Tatay, S. Org. Biomol. Chem. 2014, 12, 7572. (k) Fahrenbach, A. C.; Bruns, C. J.; Li, H.; Trabolsi, A.; Coskun, A.; Stoddart, J. F. Acc. Chem. Res. 2014, $47,482$.

(6) For examples of chemically-driven molecular shuttles, see: (a) Martínez-Díaz, M.-V.; Spencer, N.; Stoddart, J. F. Angew. Chem., Int. Ed. Engl. 1997, 36, 1904. (b) Elizarov, A. M.; Chiu, S.H.; Stoddart, J. F. J. Org. Chem. 2oo2, 67, 9175. (c) Leigh, D. A. Pérez, E. M. Chem. Commun. 2004, 2262.

(7) For examples of cation-induced shuttling, see: (a) Vignon, S. A.; Jarrosson, T.; Iijima, T.; Tseng, H.-R., Sanders, J. K. M.; Stoddart, F. J. Am. Chem. Soc. 2004, 126, 9884. (b) Marlin, D. S.; González Cabrera, D.; Leigh, D. A.; Slawin, A. M. Z. Angew. Chem., Int. Ed. 2006, 45, 77. (c) Marlin, D. S.; González Cabrera, D.; Leigh, D. A.; Slawin, A. M. Z. Angew. Chem., Int. Ed. 2006, 45, 1385. (d) Crowley, J. D.; Hänni, K. D.; Leigh, D. A. Slawin, A. M. Z. J. Am. Chem. Soc. 2010, 132, 5309. (e) Lewis, J. E. M.; Bordoli, R. J.; Denis, M.; Fletcher, C. J.; Galli, M.; Neal, E. A.; Rochette, E. M.; Goldup, S. M. Chem. Sci. 2016, 7, 3154.

(8) For examples of anion-induced shuttling, see: (a) Keaveney, C. M.; Leigh, D. A. Angew. Chem., Int. Ed. 2004, 43, 1222. (b) Lin, C.-F.; Lai, C.-C.; Liu, Y.-H.; Peng, S.-M. Chiu, S.-H. Chem.Eur. J. 2007, 13, 4350. (c) Lin, T.-C.; Lai, C.-C.; Chiu, S.-H. Org. Lett. 2009, 11, 613. (d) You, Y.-C.; Tzeng, M.-C.; Lai, C.-C.; Chiu, S.-H. Org. Lett. 2012, 14, 1046. (e) Zhang, H.; Hu, J.; Qu, D.-H. Org. Lett. 2012, 14, 2334. (f) Raju, M. V. R.; Lin, H.-C. Org. Lett. 2013, 15, 1274. (g) Collins, C. G.; Peck, E. M.; Kramer, P. J.; Smith, B. D. Chem. Sci. 2013, 4, 2557.

(9) (a) Balzani, V.; Credi, A.; Raymo, F. M.; Stoddart, J. F. Angew. Chem., Int. Ed. 2ooo, 39, 3349. (b) Browne, W. R.; Feringa, B. L. Nat. Nanotech. 2006, 1, 25. (c) Tian, H.; Wang, Q.-C. Chem. Soc. Rev. 2006, 35, 361. (d) Kay, E. R.; Leigh, D. A.; Zerbetto, F. Angew. Chem., Int. Ed. 2007, 46, 72. (e) Erbas-Cakmak, S.; Leigh, D. A.; McTernan, C. T.; Nussbaumer, A. L. Chem. Rev. 2015, 115, 10081. (f) Leigh, D. A. Angew. Chem., Int. Ed. 2016, 55, 14506.

(10) (a) Benniston, A. C. Chem. Soc. Rev. 1996, 25, 427. (b) Murakami, H.; Kawabuchi, A.; Kotoo, K.; Kunitake, M.; Nakashima, N. J. Am. Chem. Soc. 1997, 119, 7605. (c) Blanco, M.J.; Jiménez, M. C.; Chambron, J.-C.; Heitz, V.; Linke, M.; Sauvage, J. -P Chem. Soc. Rev. 1999, 28, 293. (d) Ashton, P. R.; Ballardini, R.; Balzani, V.; Credi, A.; Dress, K. R.; Ishow, E.; Kleverlaan, C. J.; Kocian, O.; Preece, J. A.; Spencer, N.; Stoddart, J. F.; Venturi, M.; Wenger, S. Chem.-Eur. J. 2ooo, 6 , 3558. (e) Wurpel, G. W. H.; Brouwer, A. M.; van Stokkum, I. H. M.; Farran, A.; Leigh, D. A. J. Am. Chem. Soc. 2oo1, 123, 11327. (f) Brouwer, A. M.; Frochot, C.; Gatti, F. G.; Leigh, D. A.; Mottier, 
L.; Paolucci, F.; Roffia, S.; Wurpel, G. W. H. Science 2001, 291, 2124. (g) Stanier, C. A.; Alderman, S. J.; Claridge, T. D. W.; Anderson, H. L. Angew. Chem., Int. Ed. 2002, 41, 1769. (h) Altieri, A.; Bottari, G.; Dehez, F.; Leigh, D. A.; Wong, J. K. Y.; Zerbetto, F. Angew. Chem., Int. Ed. 2003, 42, 2296. (i) Gatti, F. G.; Lent, S.; Wong, J. K. Y.; Bottari, G.; Altieri, A.; Morales, M. A. F.; Teat, S. J.; Frochot, C.; Leigh, D. A.; Brouwer, A. M.; Zerbetto, F. Proc. Natl. Acad. Sci. U.S.A. 2003, 100, 10. (j) Peréz, E. M.; Dryden, D. T. F.; Leigh, D. A.; Teobaldi, G.; Zerbetto, F. J. Am. Chem. Soc. 2004, 126, 12210. (k) Weidong, Z.; Dugang, C.; Junbo, L.; Jialiang, X.; Jing, L.; Huibiao L.; Yuliang, L. Org. Lett. 2007, 9, 3929. (l) Saha S. Stoddart, J. F. Chem. Soc. Rev., 2007, 36, 77. (m) Hirose, K.; Shiba, Y.; Ishibashi, K.; Doi; Tobe, Y. Chem.-Eur. J. 2008, 14, 3427. (n) Ma, X.; Tian, H. Chem. Soc. Rev. 2010, 39, 70. (o) Zhang, H.; Kou, X. X.; Zhang, Q.; Qu, D. H.; Tian, H. Org. Biomol. Chem. 2o11, 9, 4051. (p) MartinezCuezva, A.; Valero-Moya, S.; Alajarin M.; Berná, J. Chem. Commun. 2015, 51, 14501. (q) Qu, D.-H.; Wang, Q.-C.; Zhang, Q.-W.; Ma, X.; Tian, H. Chem. Rev. 2015, 115, 7543. (r) Zhan, T.G.; Yun, M.-Y.; Lin, J.-L.; Yu, X.-Y.; Zhang, K.-D. Chem. Commun. 2016, 52, 14085. (s) Tron, A.; Pianet, I.; Martinez-Cuezva, A.; Tucker, J. H. R.; Pisciottani, L.; Alajarin, M.; Berna, J.; McClenaghan, N. D. Org. Lett. 2017, 19, 154. (t) MartinezCuezva, A.; Saura-Sanmartin, A.; Nicolas-Garcia, T.; Navarro, C.; Orenes, R.-A.; Alajarin, M.; Berna, J. Chem. Sci., 2017, doi: $10.1039 / \mathrm{C}_{7} \mathrm{SCoO}_{724} \mathrm{H}$.

(11) For a review of amide-based molecular shuttles, see: (a) Berná, J.; Bottari, G.; Leigh, D. A.; Peréz, E. M. Pure Appl. Chem. 2007, 79, 39. For selected examples of amide-based molecular shuttles, see: (b) Lane, A. S.; Leigh, D. A.; Murphy, A. J. Am. Chem. Soc. 1997, 119, 11092. (c) Altieri, A.; Gatti, F. G.; Kay, E. R.; Leigh, D. A.; Martel, D.; Paolucci, F.; Slawin, A. M. Z.; Wong, J. K. Y. J. Am. Chem. Soc. 2003, 125, 8644. (d) Leigh, D. A.; Morales, M. A. F.; Peréz, E. M.; Wong, J. K. Y.; Saiz, C. G.; Slawin, A. M. Z.; Carmichael, A. J.; Haddleton, D. M.; Brouwer, A. M.; Buma, W. J.; Wurpel, G. W. H.; Leon, S.; Zerbetto, F. Angew. Chem., Int. Ed. 2005, 44, 3062. (e) Berná, J.; Goldup, S. M.; Lee, A.-L.; Leigh, D. A.; Symes, M. D.; Teobaldi, G.; Zerbetto, F. Angew. Chem., Int. Ed. 20o8, 47, 4392. (f) Berná, J.; Alajarin, M.; Orenes, R. A., J. Am. Chem. Soc. 2010, 132, 10741. (g) Crowley, J. D.; Hänni, K. D.; Leigh, D. A.; Slawin, A. M. Z. J. Am. Chem. Soc. 2010, 132, 5309. (h) Berná, J.; Alajarin, M.; Marin- Rodriguez, C.; Franco-Pujante, C. Chem. Sci. 2012, 3, 2314. (i) Caballero, C.; Swan, L.; Zapata, F.; Beer, P. D. Angew. Chem., Int. Ed. 2014, 53, 11854. (j) Martinez-Cuezva, A.; Berná, J.; Orenes, R.-A.; Pastor A.; Alajarin, M. Angew. Chem., Int. Ed. 2014, 53, 6762. (k) Berná, J.; Franco-Pujante, C.; Alajarin, M. Org. Biomol. Chem. 2014, 12, 474. (l) Martinez-Cuezva, A.; Pastor, A.; Cioncoloni, G.; Oranes, R.-A.; Alajarin, M.; Symes, M. D.; Berná, J. Chem. Sci. 2015, 6, 3087. (m) Martinez-Cuezva, A.; Carro-Guillen, F.; Pastor, A.; Marin-Luna, M.; Orenes, R.-A.; Alajarin, M.; Berná, J. Chem. Phys. Chem. 2016, 17, 1920. (n) Barendt, T. A.; Robinson, S. W.; Beer, P. D. Chem. Sci. 2016, 7, 5171.

(12) (a) Chaur, M. N.; Collado, D.; Lehn, J. M. Chem.-Eur. J. 2011, 17, 248. (b) Vantomme, G.; Hafezi, N.; Lehn, J. M. Chem. Sci. 2014, 5, 1475. (c) van Dijken, D. J.; Kovaříček, P.; Ihrig, S. P.; Hecht, S. J. Am. Chem. Soc. 2015, 137, 14982. For molecular machines incorporating hydrazones, see. (d) Su, X.; Aprahamian, I. Org. Lett. 2011, 13, 30. (e) Su, X.; Robbins, T. F.; Aprahamian, I. Angew. Chem., Int. Ed. 2011, 50, 1841. (f) Ray, D.; Foy, J. T.; Hughes, R. P.; Aprahamian, I. Nature Chem. 2012, 4, 757. (g) Kassem, S.; Lee, A. T. L.; Leigh, D. A.; Markevicius, A.; Solà, Nature Chem. 2016, 8, 138.
(13) (a) Johnston, A. G.; Leigh, D. A.; Nezhat, L.; Smart, J. P.; Deegan, M. D. Angew. Chem., Int. Ed. Engl. 1995, 34, 1212. (b) Johnston, A. G.; Leigh, D. A.; Pritchard, R. J.; Deegan, M. D. Angew. Chem., Int. Ed. Engl. 1995, 34, 1209. (c) Johnston, A. G.; Leigh, D. A.; Murphy, A.; Smart, J. P.; Deegan, M. D. J. Am. Chem. Soc. 1996, 118, 10662. (d) Leigh, D. A.; Murphy, A.; Smart, J. P.; Slawin, A. M. Z. Angew. Chem., Int. Ed. 1997, 36, 728. (e) Clegg, W.; Gimenez-Saiz, C.; Leigh, D. A.; Murphy, A.; Slawin, A. M. Z.; Teat, S. J. J. Am. Chem. Soc. 1999, 121, 4124. (f) Bermudez, V.; Capron, N.; Gase, T.; Gatti, F. G.; Kajzar, F.; Leigh, D. A.; Zerbetto, F.; Zhang, S. Nature 20oo, 406, 6o8. (g) Gatti, F. G.; Leigh, D. A.; Nepogodiev, S. A.; Slawin, A. M. Z.; Teat, S. J.; Wong, J. K. Y. J. Am. Chem. Soc. 2001, 123, 5983. (h) Kay, E. R.; Leigh, D. A. Top. Curr. Chem. 2005, 262, 133. (i) Chatterjee, M. N.; Kay, E. R.; Leigh, D. A. J. Am. Chem. Soc. 2006, 128, 4058. (j) González Cabrera, D.; Koivisto, B. D.; Leigh, D. A. Chem. Commun. 2007, 4218. (k) Berná, J.; Brouwer, A. M.; Fazio, S. M.; Haraszkiewicz, N.; Leigh, D. A.; Lennon, C. M. Chem. Commun. 2007, 1910. (l) Alvarez-Pérez, M.; Goldup, S. M.; Leigh, D. A.; Slawin, A. M. Z. J. Am. Chem. Soc. 20o8, 130, 1836. (m) Rijs, A. M.; Compagnon, I.; Oomens, J.; Hannam, J. S.; Leigh, D. A.; Buma, W. J. J. Am. Chem. Soc. 2009, 131, 2428. (n) Fernandes, A.; Viterisi, A.; Coutrot, F.; Potok, S.; Leigh, D. A.; Aucagne, V.; Papot, S. Angew. Chem., Int. Ed. 2009, 48, 6443. (o) Rijs, A. M.; Sändig, N.; Blom, M. N.; Oomens, J.; Hannam, J. S.; Leigh, D. A.; Zerbetto, F.; Buma, W. J. Angew. Chem., Int. Ed. 2010, 49, 3896. (p) Panman, M. R.; Bodis, P.; Shaw, D. J.; Bakker, B. H.; Newton, A. C.; Kay, E. R.; Brouwer, A. M.; Buma, W. J.; Leigh, D. A.; Woutersen, S. Science 2010, 328, 1255. (q) Berná, J.; Alajarin, M.; Martinez-Espin, J. S.; Buriol, L.; Martins, M. A. P.; Orenes, R.-A. Chem. Commun. 2012, 48, 5677. (r) Panman, M. R; Bakker, B. H.; den Uyl, D.; Kay, E. R.; Leigh, D. A.; Buma, W. J.; Brouwer, A. M.; Geenevasen, J. A. J.; Woutersen, S. Nature Chem. 2013, 5, 929. (s) Martinez Cuezva, A.; Lopez-Leonardo, C.; Bautista, D.; Alajarin, M.; Berná, J. J. Am. Chem. Soc. 2016, 138, 8726.

(14) The thermal isomerization of molecular shuttle Z-6 leads exclusively to the formation of rotaxane $E-6$, either as a consequence of improved hydrogen bonding at both axle sites (in the absence of the macrocycle the succinic amide-ester can form an internal hydrogen bond via a six-membered ring), or steric effects, or a combination of the two. 


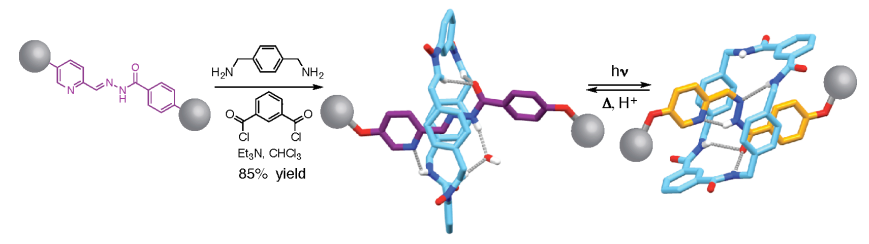

